\title{
Programme Ignobilia Oppida Lucanorum. Fouilles, prospections, études à Serra del Cedro, Civita di Tricarico et Rossano di Vaglio
}

Campagne 2018

Stéphane Bourdin et Olivier de Cazanove

\section{OpenEdition}

Journals

Édition électronique

URL : http://journals.openedition.org/cefr/3786

DOI : $10.4000 /$ cefr.3786

ISSN : 2282-5703

Éditeur

École française de Rome

Référence électronique

Stéphane Bourdin et Olivier de Cazanove, «Programme Ignobilia Oppida Lucanorum. Fouilles, prospections, études à Serra del Cedro, Civita di Tricarico et Rossano di Vaglio », Chronique des activités archéologiques de l'École française de Rome [En ligne], Italie du Sud, mis en ligne le 12 novembre 2019, consulté le 12 novembre 2019. URL : http://journals.openedition.org/cefr/3786 ; DOI : 10.4000/cefr.3786

Ce document a été généré automatiquement le 12 novembre 2019.

(c) École française de Rome 
